\title{
Morpho-anatomical characters of spermoderm of certain species of Resedaceae and their contribution to the taxonomy of the family
}

\author{
Abd El-Salam Al- Nowaihi*; \\ Eman, A.K. Karakish; \\ Ishak, F. Ishak \\ and \\ Usama, I.A. El Magly \\ Botany Department, Faculty of Science, \\ Ain Shams University, Cairo-Egypt. \\ *E-mail: abdelsalamalnowaihi@ hotmail.com
}

Al-Nowaihi, A. E.S.; Karakish, E.A.K.; Ishak, F. Ishak \& El-Magly, U.I.A. 2002. Morpho-anatomical characters of spermoderm of certain species of Resedaceae and their contribution to the taxonomy of the family. Taeckholmia 22(2):155-176.

The morphological and anatomical characters of the spermoderm of 27 species of Resedaceae were examined and described to assess the applicability of these attributes in the process of identification. Many of the recorded morphological and anatomical attributes were found to be fairly diagnostic at both the generic and specific levels. Unlike earlier claims that Reseda alba and $R$. decursiva are conspecific; the present data justify their treatment as distinct species. A correlation was found between some of the studied characters.

Key words: Resedaceae, spermoderm

\section{Introduction}

Needless to say that, in the last three decades, the morphology and the structure of the spermoderm have provided valuable clues to the taxonomy and the phylogeny of many taxa. Perhaps, the studies of Chaung \& Heckard (1983) on Scrophulariaceae and that of Bacon et al. (1986) on Hydrophyllaceae raised the feasibility of such parameters. Scanning Electron microscopy (SEM), as well, has been used as a good tool in clarifying finer details of the spermoderm and so helped in precise delimitation of many species. As far as the Resedaceae is concerned, Netolitzky (1926) studied the seed anatomy, searching for affinities of this family to some other allied taxa as Papaveraceae, Capparidaceae and Moringaceae. Corner (1976), described the morphology and anatomy of Oligomeris linifolia and four Reseda species viz. $R$. alba, $R$. lutea, $R$. luteola and $R$ odorata. Abdallah \& De Wit (1978), in their superb taxonomic revision on this family, showed that the shape and size of the seeds together with the testa layers are of much taxonomic significance.

Pemberton \& Irving (1990), reported on the occurrence of elaiosomes in 47 species belonging to 13 families including the Resedaceae. Tobe \& Raven (1991), stated that the spermoderm of the Resedaceae has most of common features with Gyrostemonaceae. 
De Leonardis et al (1997), studied the pollen and seed morphology of three Reseda species in relation to their systematic position.

To the knowledge of the present authors, no other work on the morpho- anatomical characters of the spermoderm in Resedaceae can be cited. For this purpose, the present paper aims at studying these parameters as a contribution to the taxonomy of this family.

\section{Materials and Methods}

The material represents the seeds of 27 species of the Resedaceae. Of these, 15 species are represented in the Egyptian flora (Table 1, one asterisk) and the other 12 species are foreign taxa. The seeds of both the native and the foreign species were loaned from two local herbaria and two foreign ones. Exomorphological characters were investigated by both optical and stereomicroscopes and the terminology were adopted after Murely (1951). Surface sculpture was investigated in the Unit of Electron microscopy, Faculty of Science, Ain Shams University through M5 scanning electron microscope, JEOL JSM 35C SEM, working at an accelerating voltage of $20 \mathrm{Kv}$. For anatomical investigations the seeds were soaked in water for $12 \mathrm{hrs}$, embedded in paraffin wax, microtomed at $12-15 \mu \mathrm{m}$, dehydrated and stained with safranin and light green according to the conventional method (Johansen, 1940). Drawings were made at bench level by a Camera lucida.

Table. 1. Collection data

\begin{tabular}{|c|c|c|c|}
\hline Taxon & Source & Taxon & Source \\
\hline 1-Caylusea hexagyna (Forssk.) M.L. & CAIA * & 15-R. luteola $\mathrm{L}$. & 我象* \\
\hline 2-Ochradenus baccatus Delile & CAIM* & 16- $R$. macrostachya Lange & CAIM \\
\hline 3-Oligomeris linifolia (Hornem.) Macbr. & CAIM* & 17-R. media Lagaaasca. & CAIM \\
\hline 4-Randonia africana Cosson & CAIM* & 18-R. muricata Presl & CAIM* \\
\hline 5-Reseda alba $\mathrm{L}$. & $\mathrm{CAIM}^{*}$ & 19-R. odorata L. & 界- \\
\hline 6-R. alphonsi Mull. Arg. & CAIM & 20-R. orientalis (Mull. Arg.) Boiss. & CAIM* \\
\hline 7-R. arabica Boiss. & CAIM* & 21-R. phyteuma L. & 必束* \\
\hline 8-R. complicata Bory & 舟安 & 22- $R$. pruinosa Delile & CAIM* \\
\hline 9-R. crystalina Webb. & 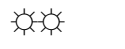 & 23-R. scoparia Brouss. & 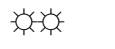 \\
\hline 10-R. decursiva Forssk. & CAIM* & 24-R. stenostachya Boiss & CAIM* \\
\hline 11-R. diffusa (Ball.) Ball. & CAIM & 25-R. stricata Pers. & CAIM \\
\hline 12-R. glauca L. & - & 26-R. urnigera Webb & CAIM* \\
\hline 13-R. lanceolata Lagasca. & CAIM & 27-R. villosa Cosson. & CAIM \\
\hline 14-R. lutea L. & CAIM* & & \\
\hline
\end{tabular}

$($ CAIA $)=$ Herbarium of the Faculty of Science, Ain Shams university, Cairo, Egypt.

$(\mathrm{CAIM})=$ Herbarium of Flora and Phytotaxonomy Research Agricultural Museum, Cairo, Egypt.

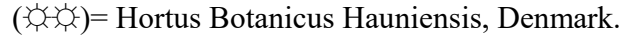

$(\phi)=$ Bereich Botanik und Arboretum Berlin, Germany.

$(*)=$ Egyptian taxa. 


\section{Results and Discussion}

\section{I- Seed morphology (Table 2, Plate 1) \\ 1-Shape of seed}

a- Reniform in Ochradenus baccatus (Fig. 2-a), Randonia Africana (Fig. 4-a), Reseda alba (Fig. 5-a), R. alphonsi (Fig. 6-a), R. arabica (Fig. 7-a), R. complicata (Fig. 8-a), $R$. decursiva (Fig. 10-a), R. diffusa (Fig. 11-a), R. glauca (Fig. 12-a), R. macrostachya (fig. 16-a ), R. media (Fig. 17-a), R. muricata (Fig. 18-a), R. odorata (Fig. 19-a), R. orientalis (Fig. 20-a), R. phyteuma (Fig. 21-a), R. pruinosa (Fig. 22-a), R. stenostachya (Fig. 24-a) and R. villosa (Fig. 27-a).

b- Ovoid in Oligomeris linifolia (Fig. 3-a), Reseda crystalina (Fig. 9-a), R. lanceolata (Fig. 13-a), R. lutea (Fig. 14-a) R. scoparia (Fig. 23-a), R. stricta (Fig. 25-a) and R. urnigera (Fig. 26-a).

c- Ovoid- pear shaped in Caylusea hexagyna (Fig. 1-a).

d- Spherical in Reseda luteola (Fig. 15-a).

With regard to the seed shape and its applicability in taxa delimitation, Grant (1924) differentiated between Mimulus spp. having an oval or oblong aspect. Also Chaung and Heckard (1983) constructed a key for the identification of the sub- taxa of genus Orthocarpus using the seed shape. In this work this character is useful at the specific level.

\section{2- Colour of seed testa}

Except for Randonia africana and Reseda phyteuma that have brown coloured testa, the latter in all other taxa shows a combination of two or more colour states (Table 2).

\section{3- Seed dimension}

The maximum length and the maximum width vary among the studied seeds. Relatively large dimensions are found in $R$. diffusa, $R$. media, $R$. odorata and $R$. orientalis while relatively small seeds are recorded in Oligomeris linifolia, Reseda muricata and $R$. stenostachya. The seed dimensions in the remainder taxa fluctuate. As to the seed size, Chuang and Heckard (1983) considered it a good tool for the classification at the specific level in case of the Scrophulariaceae. Wyatt (1984), found the same character significant in the delimitation of some Mimulus species. Argue (1986), described significant interspecific differences in seed size of some Mimulus species. Guignard (1986) in his study on the four recognized sections of Digitalis referred to four types of seeds according to seed size.

Although the foregoing authors stressed on the seed size as classificatory tools, yet Stebbins (1974) had earlier stated that the seed size is often highly adaptive.

In the present contribution both the seed colour and size do not seem to be good characters in identification, since they are inconsistent characters. In the floral organs the colour usually depends on the type of the phenolic compound(s) which acts differently towards maturation and senescence, and which is also governed by both the availability to the plant of $\mathrm{Al}^{+++}$ions in the soil and the $\mathrm{pH}$ of the cell sap. In addition, the size of the seeds is governed by the metabolic activities that also affect their number, one on the expense of the other. 


\section{4- Seed aril:}

The aril is considered as the remains of the funicle at the time when the seed becomes separated from the fruit. Since the seed of the Resedaceae is amphitropous (anacampylotropous), the aril when present, becomes adjacent to the hilum usually overtopping it and assuming the form of a tissue similar to a caruncle and thus termed carunculoid tissue. In the present work, the aril is recorded as carunculoid tissue in Reseda crystalina (Fig. 9-a), R. diffusa (Fig. 11-a), R. lutea (Fig. 14-a), R. odorata (Fig. 19-a) and R. orientalis (Fig. 20-a) and absent in the remainder taxa (Table 2). Corner (1954), claimed that the truly arillate seed is primitive in the Angiosperms but this view, as Cronquist (1968) stated, has not been widely accepted. In the present work additional criteria become necessary for judging whether the presence or absence of the aril is more primitive.

\section{5- Seed sinus}

The sinus is the slit between the radicular and the cotyledonary lobes. In the studied taxa it varies in shape and assumes the following aspects:

a- Sinus closed and represented by a shallow groove: as in Caylusea hexagyna (Fig. 1-a), Reseda crystalina (Fig. 9-a), R. lanceolata (Fig. 13-a), R. lutea (Fig. 14-a), R. scoparia (Fig. 23-a), R. stricta (Fig. 25-a) and R. urnigera (Fig. 26-a).

b- Sinus narrow in the form of an opened or slightly opened slit: as in Ochradenus baccatus (Fig. 2-a), Oligomeris linifolia (Fig. 3-a), Randonia Africana (Fig. 4-a), Reseda alba (Fig. 5-a), R. alphonsi (Fig. 6-a), R. complicata (Fig. 8-a), R. decursiva (Fig. 10-a), $R$. glauca (Fig. 12-a), $R$. luteola (Fig. 15-a), $R$. macrostachya (Fig. 16-a), R. muricata (Fig. 18-a), R. phyteuma (Fig. 21-a), R. pruinosa (Fig. 22-a), R. stenostachya (Fig. 24-a) and R. villosa (Fig. 27-a).

c- Sinus a fairly wide slit: Reseda arabica (Fig. 7-a), R. diffusa (Fig. 11-a), $R$. media (Fig. 17-a), R. odorata (Fig. 19-a) and R. orientalis (Fig. 20-a).

\section{6- Spermoderm surface as seen by SEM (Plate I, Fig. 1b- 27b)}

The following ornamentation patterns are recorded:

a- Tuberculate: The tubercles differ in different species, when their bases lateral sides and tops are considered. In Caylusea hexagyna (Fig. 1-b), the base and lateral sides are irregularly favulariate, the top is smooth to finely undulate. In Reseda alba (Fig. 5-b), the base is striate with undulate wavy margin, the lateral sides are irregularly striate and the top is undulate. In Reseda alphonsi (Fig. 6-b), the base is rectangular with the lateral sides and top striate; the top is narrow, the base, lateral sides and top are striate. In Reseda macrostachya (Fig. 16-b), the base is square, the top is very long and narrow, the base and lateral sides are rugose- striate, the top is ruminate. In Reseda muricata (Fig. 18-b), the base and lateral sides are lineate, the top is smooth. In Reseda phyteuma (Fig. 21-b), the base is wide, extending to different directions together with the lateral sides and top which are rugose. In Reseda stenostachya (Fig. 24-b), the base, lateral sides and top are striate to rugose. In Reseda villosa (Fig. 27-b), the base and the lateral sides irregularly striate, the top undulate.

b- Areolate, or areolate- scalariform in Oligomeris linifolia (Fig. 3-b), Reseda lutea (Fig. 14-b), R. luteola (Fig. 15-b), R. pruinosa (Fig. 22-b), R. scoparia (Fig. 23b) and R. stricta (Fig. 25-b).

c- Areolate with globulate areoles in Reseda crystalina (Fig. 9-b). 
d- Favulariate, rugose to ruminate with different striations. In Reseda arabica (Fig. 7-b), the areoles being delimited by the elevations which are striate. In $R$. diffusa (Fig. 11-b), the surface is rugose with lineate elevations are lineate. In $R$. media (Fig. 17-b), the surface is transversely favulariate with irregular striations in different directions in the form of a network. In R. odorata (Fig. 19-b), the surface is transversely favulariate to pusticulate; the elevations are lineate along the longitudinal axis of the cell in one direction. In R. orientalis (Fig. 20-b), the surface is favulariate to undulate- rugose, the elevations are finely striate.

e- Reticulate at the seed base and smooth to finely granulate on the whole surface in Reseda lanceolata (Fig. 13-b) and R. urnigera (Fig. 26-b).

f- Pusticulate in Reseda complicata (Fig. 8-b) and R. glauca (Fig. 12-b).

g- Colliculate with smooth elevations in Ochradenus baccatus (Fig. 2-b) and Randonia Africana (Fig. 4-b), or with rugose elevations and the bases have a wavy margin in Reseda decursiva (Fig. 10-b).

\section{II- Spermoderm anatomy (Table 3, Plate 2)}

In the present work, the spermoderm is described in terms of two components; the testa which originates from the outer integument and the tegmen which originates from the inner integument. Both the testa and the tegmen are differentiated into three layers each: exo-, meso- and endo- layers.

\section{1- Exotesta \\ A-Shape of the cell}

Papillose in Caylusea hexagyna (Fig. 1), Ochradenus baccatus (Fig. 2), Randonia Africana (Fig. 4), Reseda alba (Fig. 5), R. alphonsi (Fig. 6), R. decursiva (Fig. 10), R. macrostachya (Fig. 16), R. muricata (Fig. 18), R. phyteuma (Fig. 21), R. stenostachya (Fig. 24) and $R$. villosa (Fig. 27).

Rectangular in Oligomeris linifolia (Fig. 3), Reseda arabica (Fig. 7), R. complicate (Fig. 8), R. crystalina (Fig. 9), R. diffusa (Fig. 11), R. glauca (Fig. 12), R. lanceolata (Fig. 13), $R$. lutea (Fig. 14), R. luteola (Fig. 15), R. media (Fig. 17), R. odorata (Fig. 19), R. orientalis (Fig. 20), R. pruinosa (Fig. 22), R. scoparia (Fig. 23), R. stricta (Fig. 25) and R. urnigera (Fig. 26).

\section{B-Outer periclinal walls}

\section{a- Thickness:}

(1) Very thick as in Reseda arabica (Fig. 7), R. complicata (Fig. 8), R. diffusa (Fig. 11), R. glauca (Fig. 12), R. media (Fig. 17), R. odorata (Fig. 19), R. orientalis (Fig. 20) and $R$. stenostachya (Fig. 24).

(2) Thick as in Caylusea hexagyna (Fig. 1), Ochradenus baccatus (Fig. 2), Randonia Africana (Fig. 4), Reseda alba (Fig. 5), R. alphonsi (Fig. 6), R. decursiva (Fig. 10), $R$. macrostachya (Fig. 16), R. muricata (Fig. 18), R. phyteuma (Fig. 21) and R. villosa (Fig. 27).

(3) Thin as in Oligomeris linifolia (Fig. 3), Reseda crystalina (Fig. 9), R. lanceolata (Fig. 13), R. lutea (Fig. 14), R. luteola (Fig. 15), R. pruinosa (Fig. 22), R. scoparia (Fig. 23), R. stricta (Fig. 25) and R. urnigera (Fig. 26). 
A. E.S. Al-Nowaihi; E.A.K. Karakish; I. F. Ishak \& U.I.A. El-Magly,

b- Shape: The outer periclinal walls of the exotestal cells assume different aspects:

(1) Very convex and dentate in Caylusea hexagyna (Fig. 1), Reseda alphonsi (Fig. 6), R. macrostachya (Fig. 16), R. phyteuma (Fig. 21), R. stenostachya (Fig. 24) and R. villosa (Fig. 27).

(2) Very convex and smooth in Randonia Africana (Fig. 4) and Reseda muricata (Fig. 18).

(3) Convex with straight top in Reseda alba (Fig. 5).

(4) Slightly convex and smooth in Ochradenus baccatus (Fig. 2), or dentate in Reseda complicata (Fig. 8), R. decursiva (Fig. 10) and R. glauca (Fig. 12).

(5) Straigt and smooth in Oligomeris linifolia (Fig. 3), Reseda crystalina (Fig. 9), $R$. lanceolata (Fig. 13), R. lutea (Fig. 14), R. luteola (Fig. 15), R. pruinosa (Fig. 22), $R$. scoparia (Fig. 23), R. stricta (Fig. 25) and R. urnigera (Fig. 26).

(6) Straight and dentate as in Reseda arabica (Fig. 7), R. diffusa (Fig. 11), R. media (Fig. 17), R. odorata (Fig. 19) and R. orientalis (Fig. 20).

\section{C- Inner periclinal walls}

\section{a-Thickness:}

(1) Very thick as in Oligomeris linifolia (Fig. 3), Reseda crystalina (Fig. 9), $R$. lanceolata (Fig. 13), R. lutea (Fig. 14), R. luteola (Fig. 15), R. pruinosa (Fig. 22), $R$. scoparia (Fig. 23), R. stricta (Fig. 25) and R. urnigera (Fig. 26).

(2) Thick as in Caylusea hexagyna (Fig. 1), Ochradenus baccatus (Fig. 2), Randonia Africana (Fig. 4), $R$. alba (Fig. 5), $R$. alphonsi (Fig. 6), $R$. arabica (Fig. 7), $R$. complicata (Fig. 8), R. decursiva (Fig. 10), R. diffusa (Fig. 11), R. glauca (Fig. 12), $R$. macrostachya (Fig. 16), R. media (Fig. 17), R. muricata (Fig. 18), R. odorata (Fig. 19), $R$. orientalis (Fig. 20), R. phyteuma (Fig. 21), R. stenostachya (Fig. 24) and R. villosa (Fig. 27).

\section{b- Shape:}

(1) Convex, smooth in Oligomeris linifolia (Fig. 3).

(2) Convex, wavy in Reseda crystalina (Fig. 9).

(3) Convex, dentate in Reseda stricta (Fig. 25).

(4) Convex, smooth in Reseda lutea (Fig. 14) and R. scoparia (Fig. 23).

(5) Concave, warty in Reseda luteola (Fig. 15).

(6) Concave granulate in Reseda lanceolata (Fig. 13) and R. urnigera (Fig. 26)

(7) Concave, dentate in Reseda pruinosa (Fig. 22).

(8) Straight and smooth as Caylusea hexagyna (Fig. 1), Ochradenus baccatus (Fig. 2), Randonia Africana (Fig. 4), Reseda alba (Fig. 5), R. alphonsi (Fig. 6), $R$. arabica (Fig. 7), R. complicata (Fig. 8), R. decursiva (Fig. 10), R. diffusa (Fig. 11), R. glauca (Fig. 12), R. macrostachya (Fig. 16), R. media (Fig. 17), R. muricata (Fig. 18), R. odorata (Fig. 19), R. orientalis (Fig. 20), R. phyteuma (Fig. 21), R. stenostachya (Fig. 24) and R. villosa (Fig. 27).

\section{D- Anticlinal walls}

(1)- Thickening wedge- shaped on the lower part of the primary walls in Oligomeris linifolia (Fig. 3), Reseda crystalina (Fig. 9), R. lanceolata (Fig. 13), R. lutea (Fig. 14), R. luteola (Fig. 15), R. pruinosa (Fig. 22), R. scoparia (Fig. 23), R. stricta (Fig. 25) and R. urnigera (Fig. 26). 
(2)- Thickening all over the walls in Caylusea hexagyna (Fig. 1), Ochradenus baccatus (Fig. 2), Randonia Africana (Fig. 4), Reseda alba (Fig. 5), R. alphonsi (Fig. 6), R. arabica (Fig. 7), R. complicata (Fig. 8), R. decursiva (Fig. 10), R. diffusa (Fig. 11), R. glauca (Fig. 12), R. macrostachya (Fig. 16), R. media (Fig. 17), R. muricata (Fig. 18), R. odorata (Fig. 19), R. orientalis (Fig. 20), R. phyteuma (Fig. 21), R. stenostachya (Fig. 24) and R. villosa (Fig. 27).

\section{2- Mesotesta}

This is absent in all studied taxa except in Caylusea hexagyna (Fig. 1) where it is formed of one layer of coloured rectangular thick walled cells.

\section{3- Endotesta}

a- One- layered of thick walled pentagonal cells or penta- hexagonal cells. This layer is isocrystaliferous (containing crystals) as in Caylusea hexagyna (Fig. 1), Ochradenus baccatus (Fig. 2), Reseda crystalina (Fig. 9), R. lutea (Fig. 14) and R. stricta (Fig. 25), or non crystaliferous in Randonia africana (Fig. 4), Reseda alba (Fig. 5), $R$. alphonsi (Fig.6), R. complicate (Fig. 8), R. decursiva (Fig. 10), R. glauca (Fig. 12), R. lanceolata (Fig. 13), R. luteola (Fig. 15), R. macrostachya (Fig. 16), R. muricata (Fig. 18), $R$. phyteuma (Fig. 21), R. pruinosa (Fig. 22), R. scoparia (Fig. 23), R. stenostachya (Fig. 24), $R$. urnigera (Fig. 26) and $R$. villosa (Fig. 27).

b- Multi- layered, of irregular isodiametric cells which are crystaliferous in Reseda arabica (Fig. 7), R. diffusa (Fig. 11), R. odorata (Fig. 19) or non crystaliferous in Reseda media (Fig. 17) and R. orientalis (Fig. 20).

c- In the form of one to two layers of irregular isodiametric cells in Oligomeris linifolia (Fig. $3)$.

\section{4- Exotegmen}

In all the studied taxa have one layer of luminate equal or unequal stone cells.

\section{5- Mesotegmen}

In all studied taxa, the mesotegmen consists of one layer of rectangular more or less narrow cells with wavy anticlinal walls.

\section{6- Endotegmen}

In all studied taxa, the endotegmen consists of one layer of wide rectangular thin walled cells except for Oligomeris linifolia (Fig. 3) which has two or three layers.

In the light of the observations on the seed shape, spermoderm sculpture and spermoderm anatomy as well as some other characters, the two following keys are contructed. 
A. E.S. Al-Nowaihi; E.A.K. Karakish; I. F. Ishak \& U.I.A. El-Magly, 
Morpho-anatomical characters of spermoderm of certain species of Resedaceae 
A. E.S. Al-Nowaihi; E.A.K. Karakish; I. F. Ishak \& U.I.A. El-Magly,

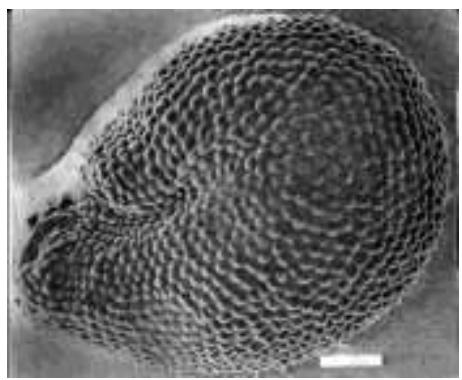

1-a

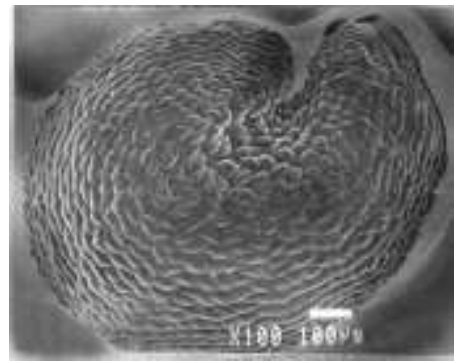

2-a

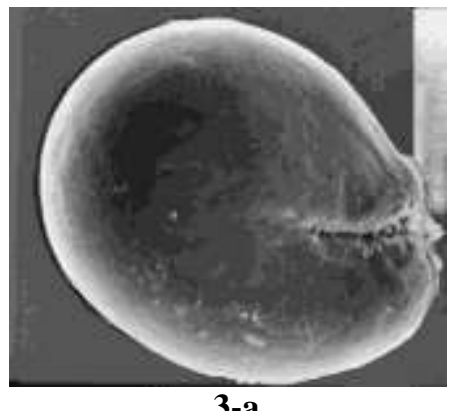

3-a

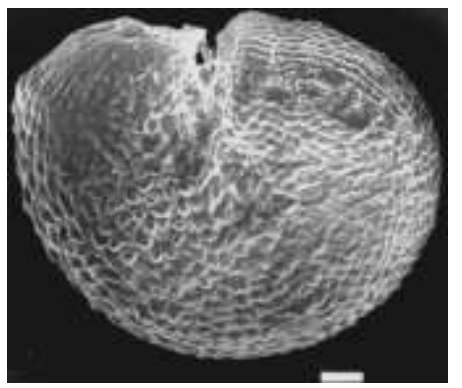

4-a

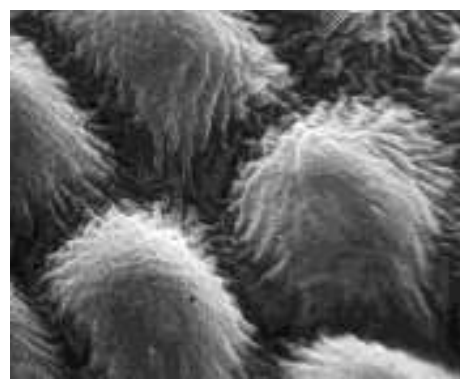

1-b

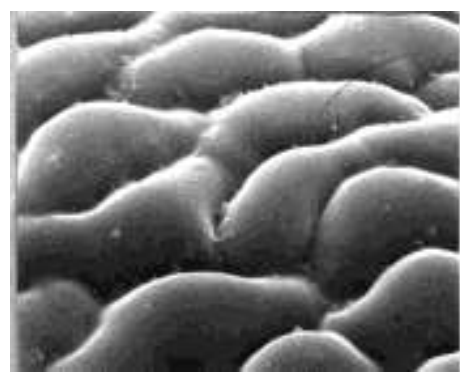

2-b

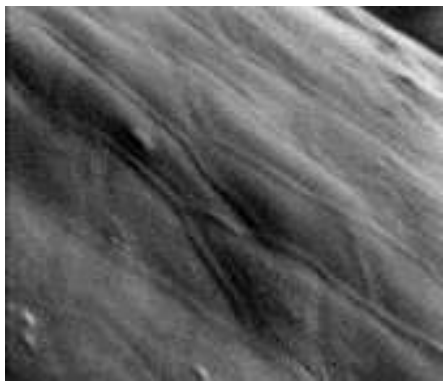

3-b

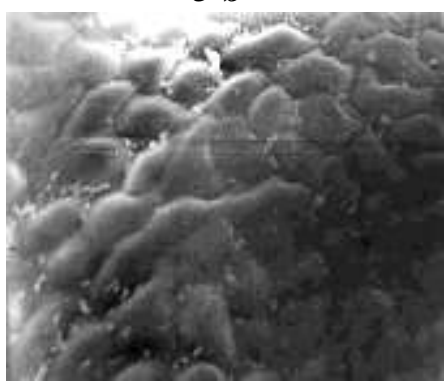

4-b

Plate 1- Exomorphology of the seeds under SEM, a- seed shape, b-spermoderm. Fig.1: Caylusea hexagyna; a-x120, b-x1200.

Fig.2: Ochradenus baccatus; a-x100, b-x600.

Fig.3: Oligomeris linifolia; a-x150, b-x1500.

Fig.4: Randonia afrlicana; a-x80, b-x300. 


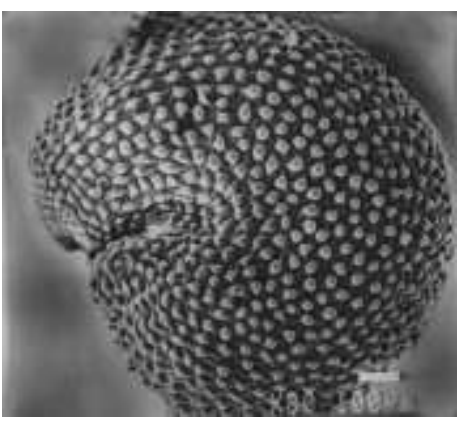

5-a

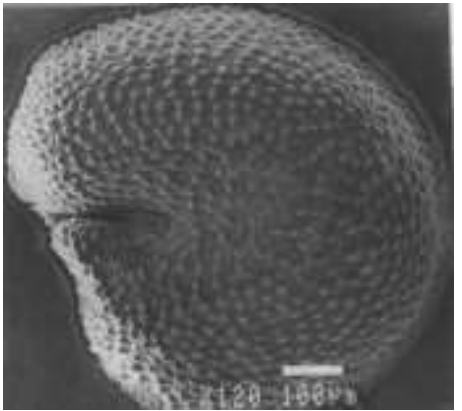

6-a

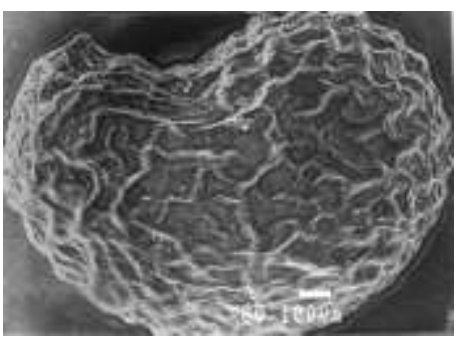

7-a

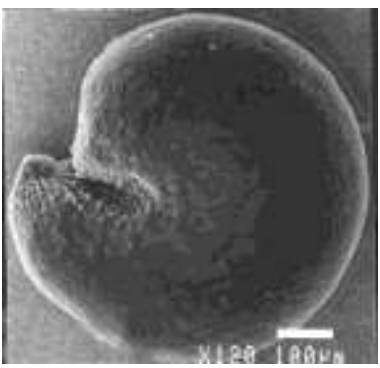

8-a

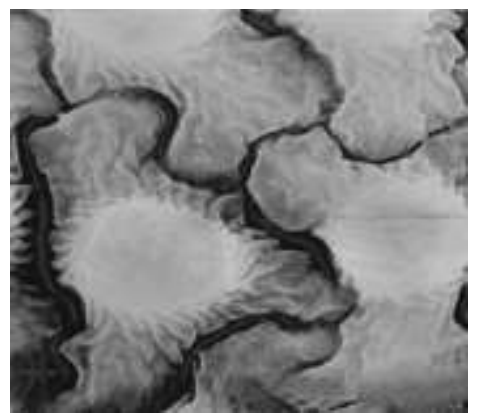

5-b

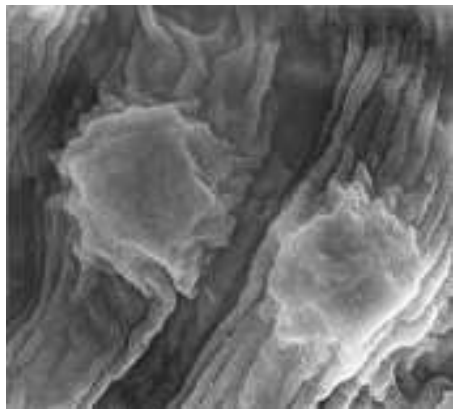

6-b

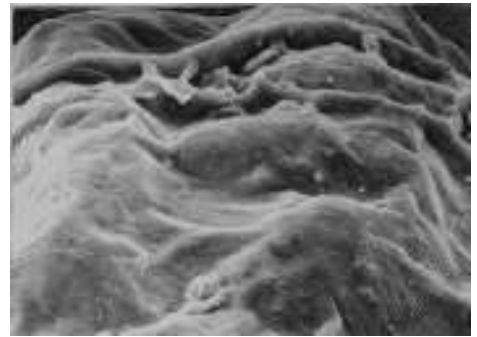

7-b

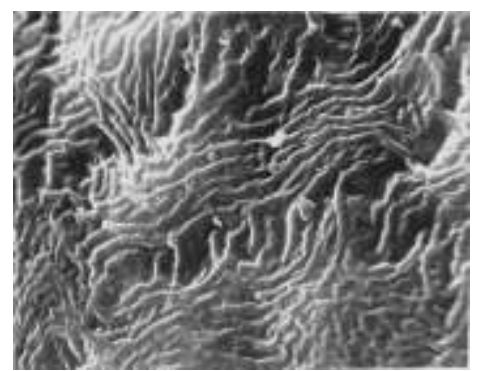

8-b

Plate 1- Exomorphology of the seeds under SEM (Cont.), a- seed shape, b-spermoderm. Fig.5: Reseda alba; $\mathrm{a}-\mathrm{x} 80, \mathrm{~b}-\mathrm{x} 1200$.

Fig.6: Reseda alphonsi; a-x120, b-x1200.

Fig.7: Reseda arabica; $\mathrm{a}-\mathrm{x} 80, \mathrm{~b}-\mathrm{x} 300$.

Fig.8: Reseda complicata; a-x120, b-x400. 
A. E.S. Al-Nowaihi; E.A.K. Karakish; I. F. Ishak \& U.I.A. El-Magly,

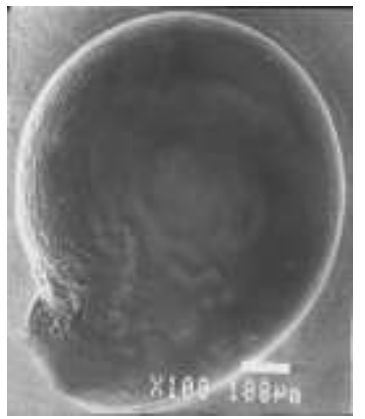

9-a

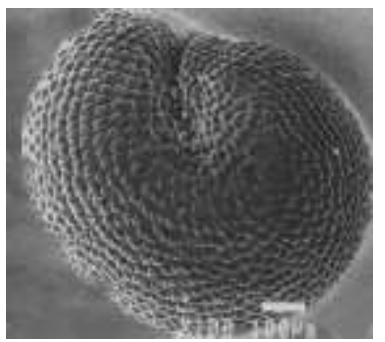

10-a

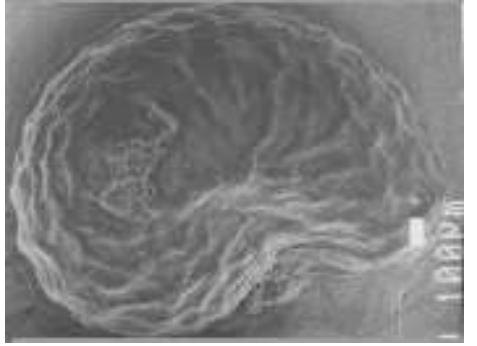

11-a

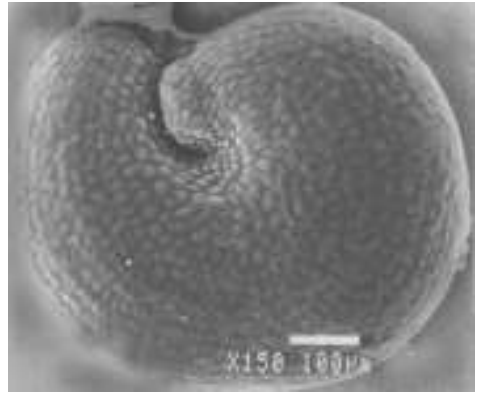

12-a

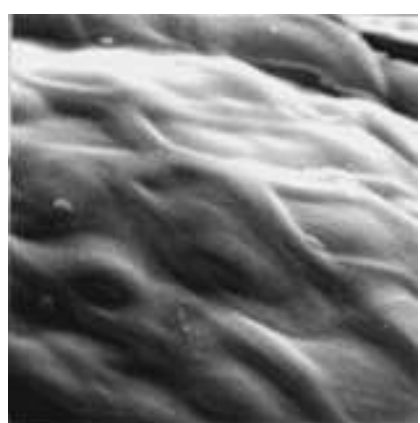

9-b

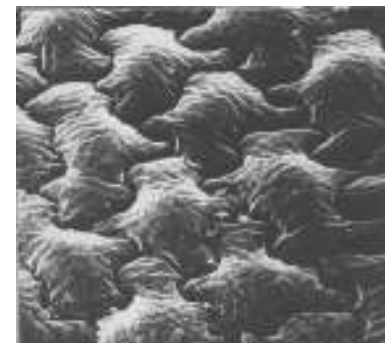

10-b

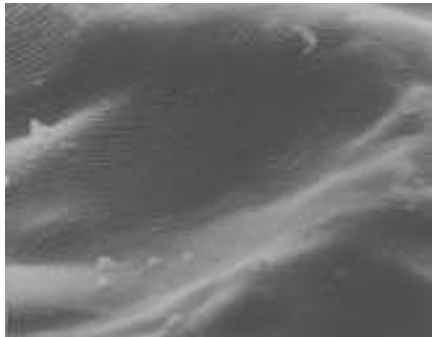

11-b

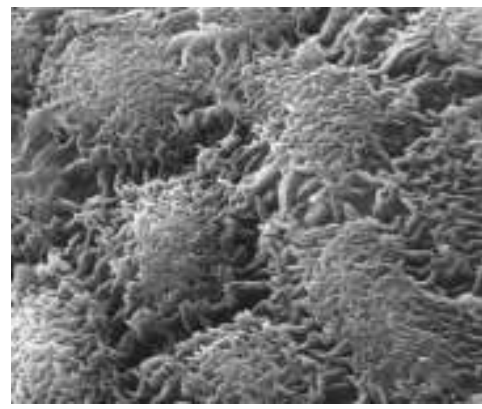

12-b

Plate 1- Exomorphology of the seed under SEM (Cont.), a-seed shape, b-spermoderm.

Fig.9: $R$. crystalina; $\mathrm{a}-\mathrm{x} 100, \mathrm{~b}-\mathrm{x} 800$.

Fig.10: $R$. decursiva; a-x100, b-x600.

Fig.11: $R$. diffuse; $\mathrm{a}-\mathrm{x} 40, \mathrm{~b}-\mathrm{x} 800$.

Fig.12: $R$. glauca; a-x150, b-x1200. 
Morpho-anatomical characters of spermoderm of certain species of Resedaceae

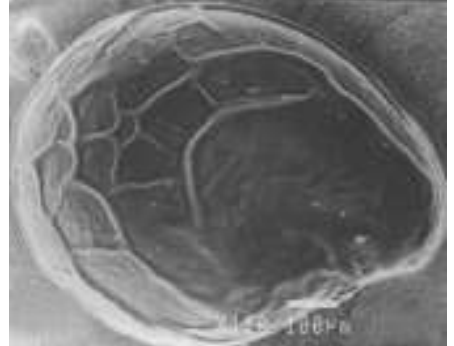

13-a

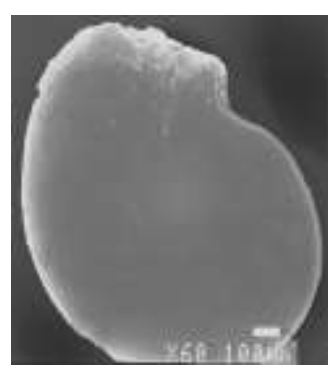

14-a

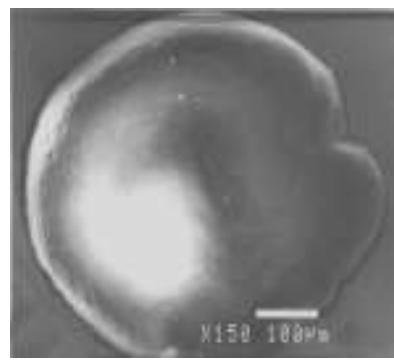

15-a

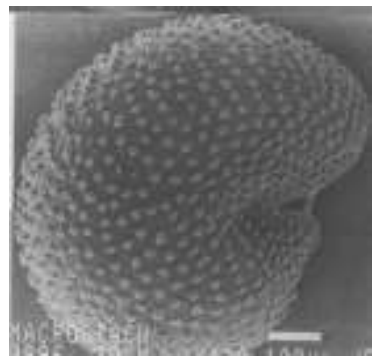

16-a

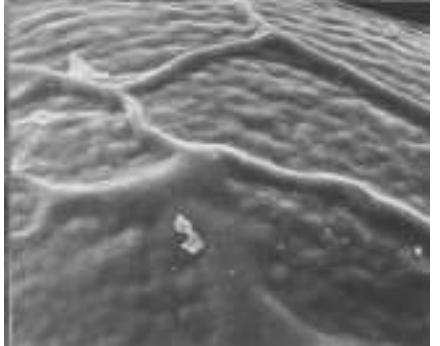

13-b

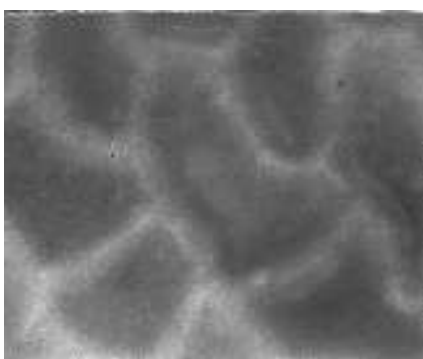

14-b

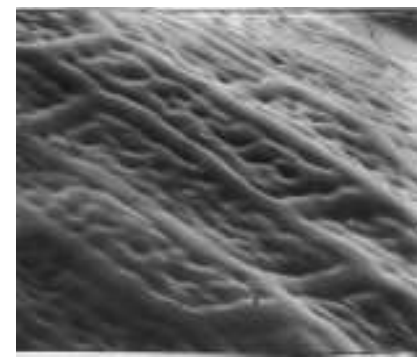

15-b

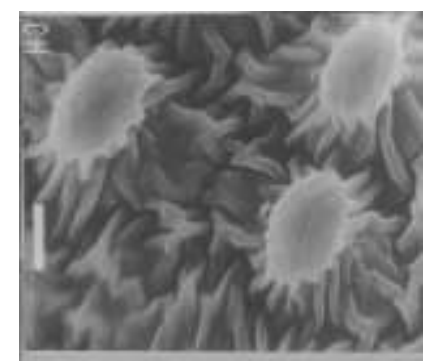

16-b

Plate 1- Exomorphology of the seeds under SEM (Cont.), a-seed shape, b-spermoderm.

Fig.13: R. lanceolata; a-x120, b-x400.

Fig.14: R. lutea; a-x60, b-x800.

Fig.15: R. luteola; a-x150, b-x1500.

Fig.16: $R$. macrostachya; a-x120, b-x1200. 
A. E.S. Al-Nowaihi; E.A.K. Karakish; I. F. Ishak \& U.I.A. El-Magly,

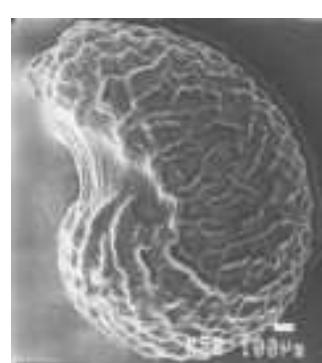

17-a

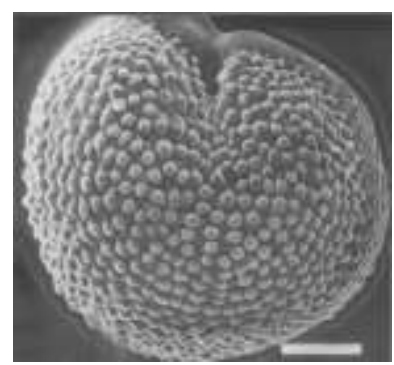

18-a

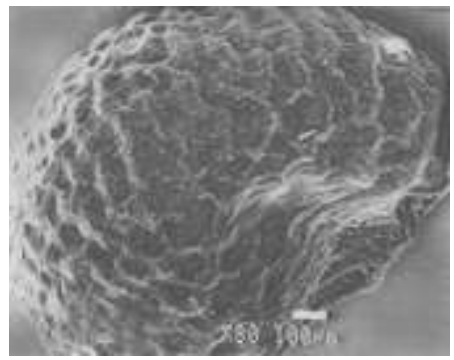

19-a

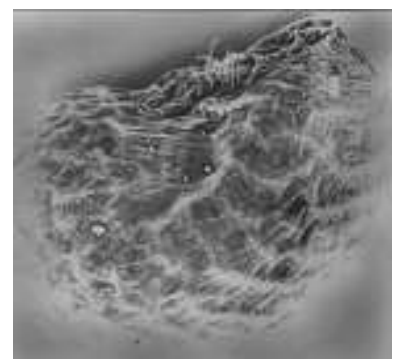

20-a

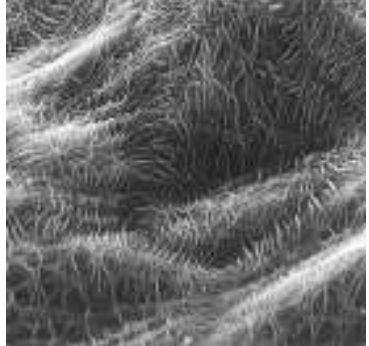

17-b

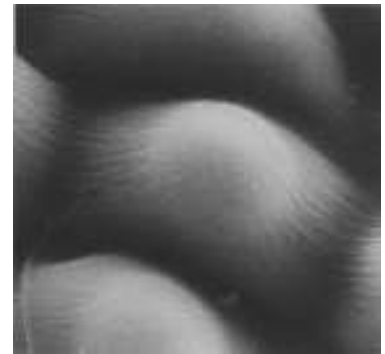

18-b

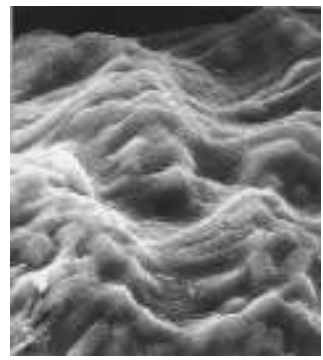

19-b

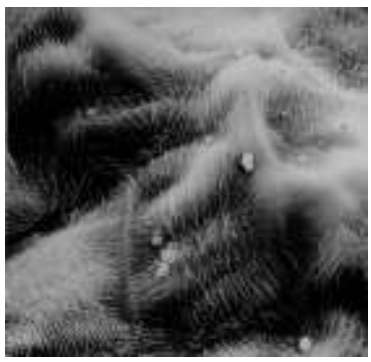

20-b

Plate 1- Exomorphology of the seeds under SEM (Cont.), a-seed shape, b-spermoderm.

Fig.17: R. media; a-x50, b-x1200.

Fig.18: $R$. muricata; $\mathrm{a}-\mathrm{x} 150, \mathrm{~b}-\mathrm{x} 1200$.

Fig.19: $R$. odorata; $\mathrm{a}-\mathrm{x} 80, \mathrm{~b}-\mathrm{x} 400$.

Fig.20: $R$. orientalis; $\mathrm{a}-\mathrm{x} 50, \mathrm{~b}-\mathrm{x} 800$. 


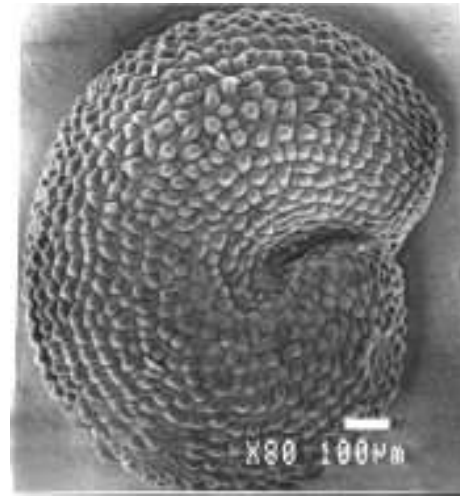

21-a

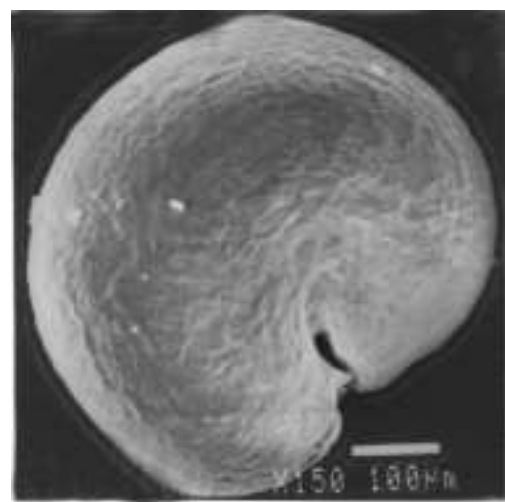

22-a

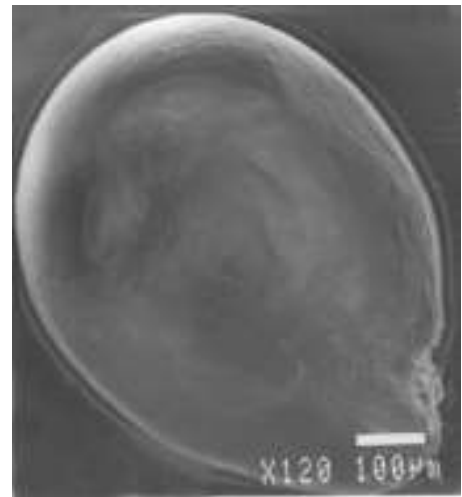

23-a

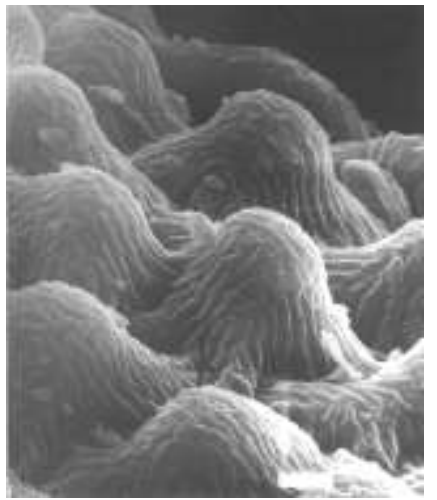

21-b

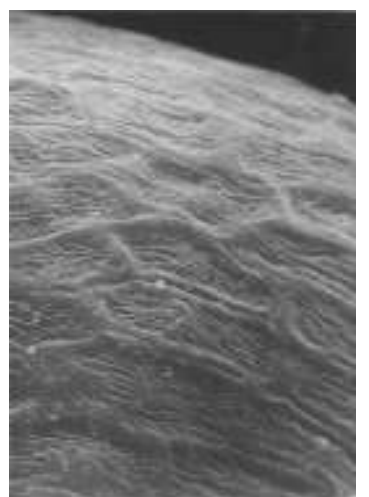

22-b

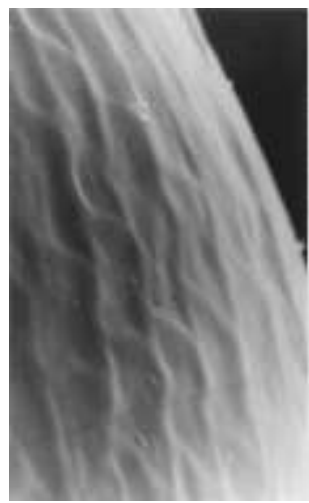

23-b

Plate 1- Exomorphology of the seeds under SEM (Cont.), a-seed shape, b-spermodarm.

Fig.21: R. phyteuma; a-x80, b-x800.

Fig.22: $R$. pruinosa; a-x150, b-x800.

Fig.23: R. scoparia; a-x120, b-x1200. 
A. E.S. Al-Nowaihi; E.A.K. Karakish; I. F. Ishak \& U.I.A. El-Magly,

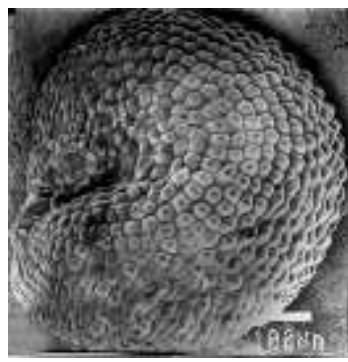

24-a
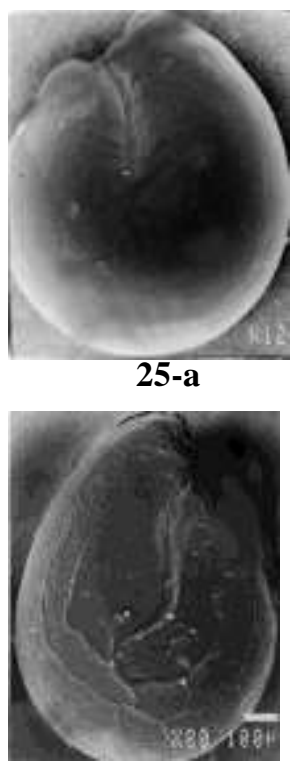

26-a

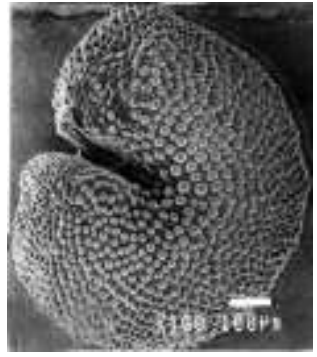

27-a

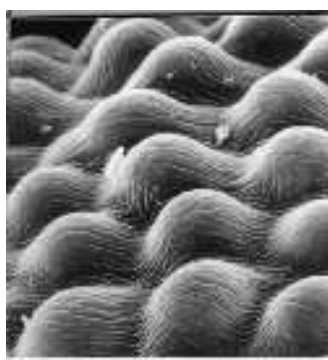

24-b

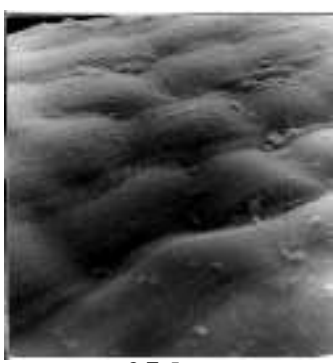

25-b

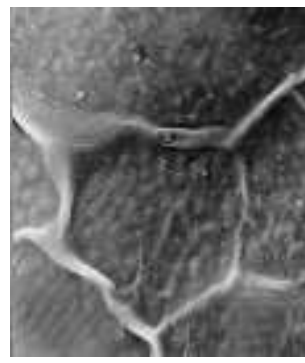

26-b

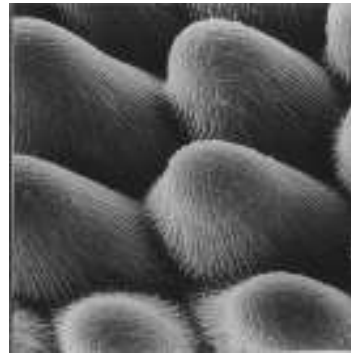

27-b

Plate 1- Exomorphology of the seeds under SEM (Cont.), a-seed shape, b-spermoderm.

Fig.24: R. stenostachya; a-x150, b-x1000.

Fig.25: R. stricta; a-x120, b-x2000.

Fig.26: $R$. urnigera; $\mathrm{a}-\mathrm{x} 800, \mathrm{~b}-\mathrm{x} 250$.

Fig.27: R. villosa; $\mathrm{a}-\mathrm{x} 100, \mathrm{~b}-\mathrm{x} 1500$. 


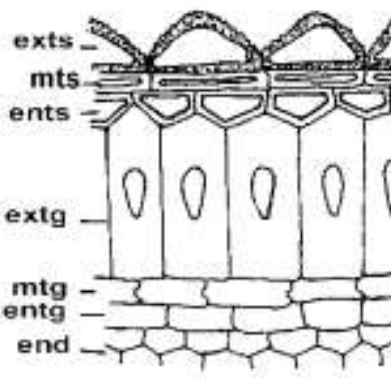

1

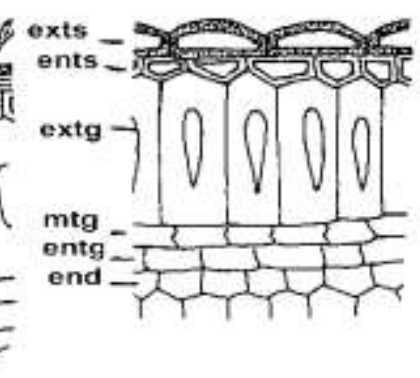

2

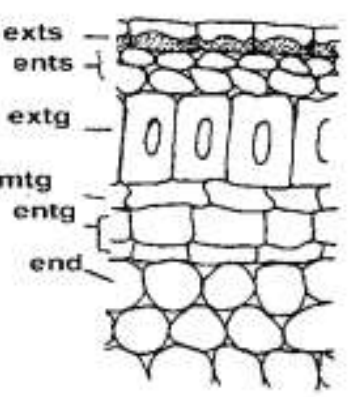

3

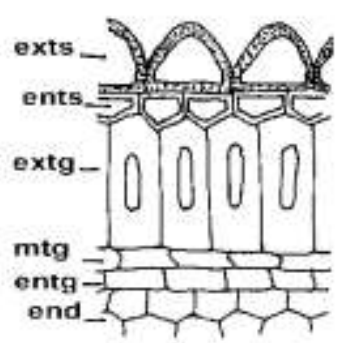

4

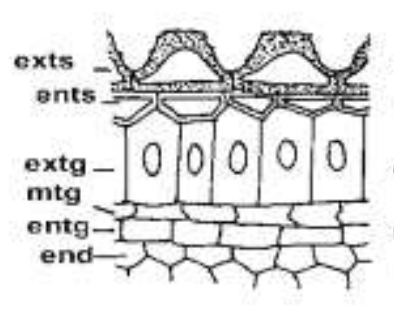

5

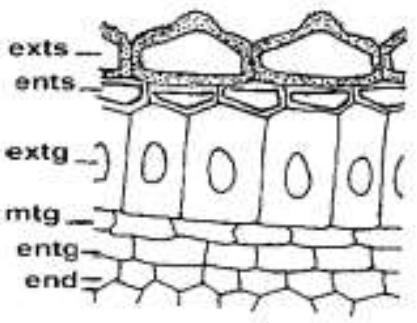

6

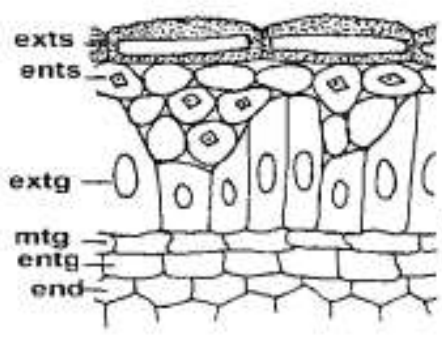

7

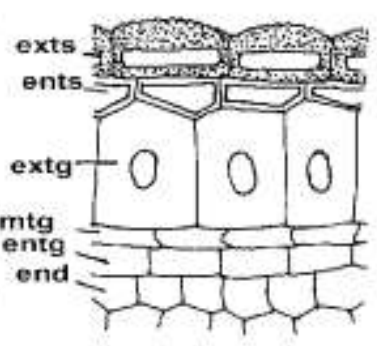

8

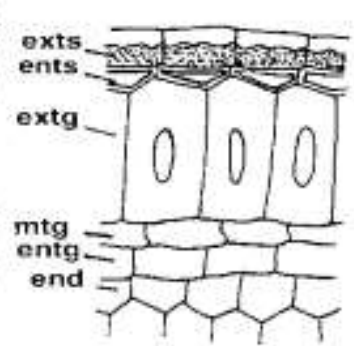

9

Plate 2. Spermoderm anatomy.

Fig. 1. Caylusea hexagyna, Fig. 2. Ochradenus baccatus,

Fig. 3. Oligomeris linifolia, Fig. 4. Randonia Africana,

Fig. 5. Reseda alba, Fig. 6. R. alphonsi, Fig. 7. R. arabica,

Fig. 8. R. complicate, Fig. 9. $R$. crystalina.

end=Endosperm; entg=Endotegmen; ents=Endotesta; extg=Exotegmen; exts=Exotesta; $\mathrm{mtg}=$ Mesotegmen; $\mathrm{mts}=$ Mesotesta. 


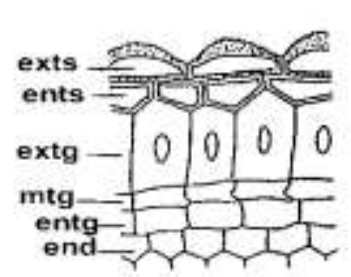

10

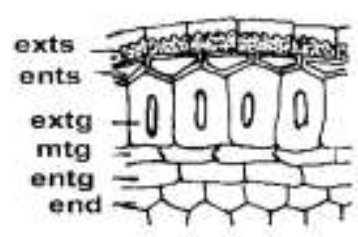

13

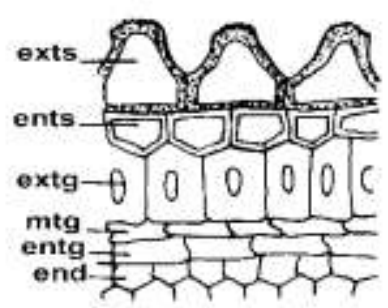

16

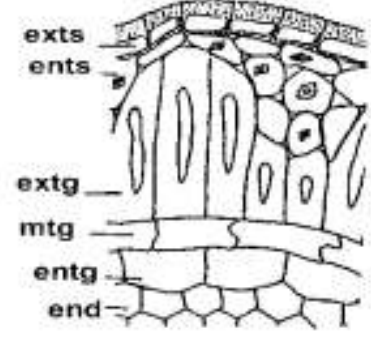

11

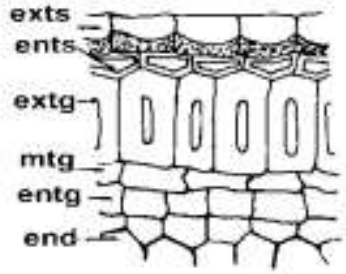

14

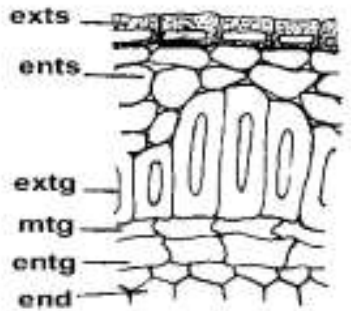

17

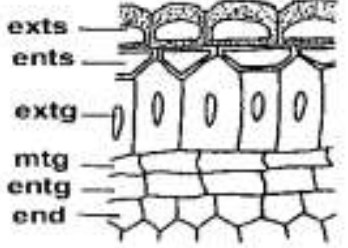

12

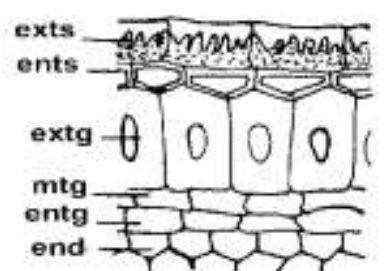

15

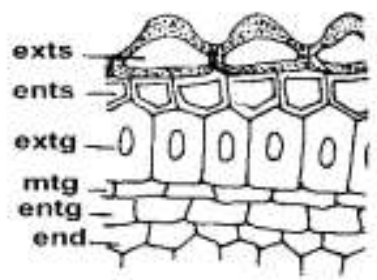

18

Plate 2. Spermoderm anatomy (cont.).

Fig. 10. R.decursiva, Fig. 11. R.diffusa,

Fig. 12. $R$. glauca, Fig. 13. $R$. lanceolata,

Fig. 14. $R$. lutea, Fig. 15. $R$. luteola,

Fig. 16. $R$. macrostachya, Fig. 17. $R$. media, Fig. 18. $R$. muricata $R$. muricata. end=Endosperm; entg=Endotegmen; ents=Endotesta; extg=Exotegmen; exts=Exotesta; $\mathrm{mtg}=$ Mesotegmen; $\mathrm{mts}=$ Mesotesta. 


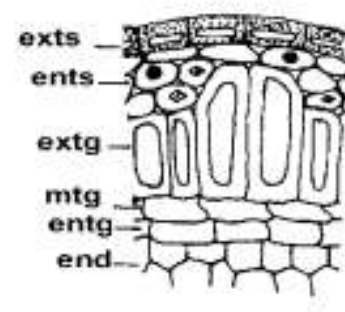

19

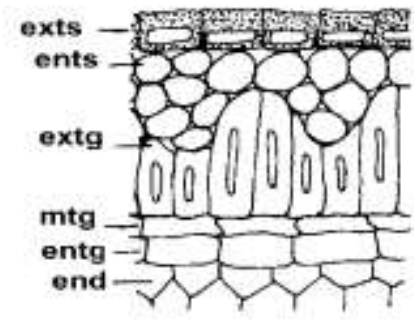

20

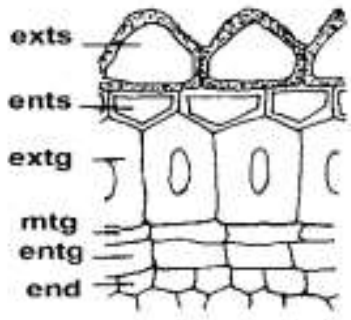

21

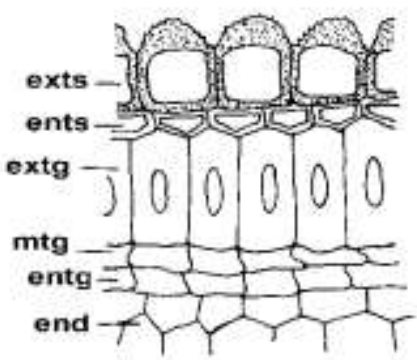

24

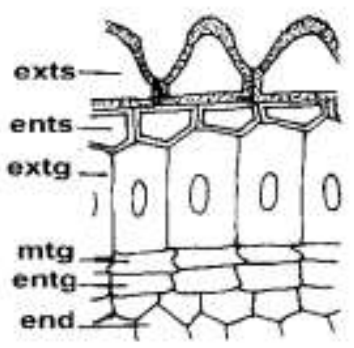

27

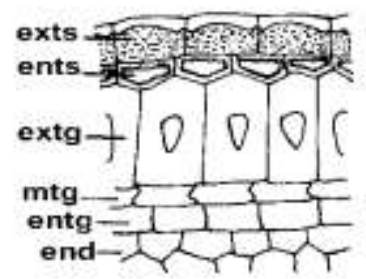

25

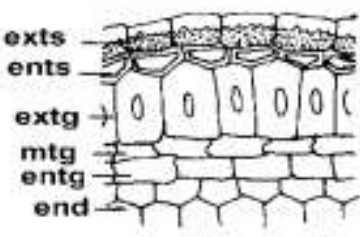

26

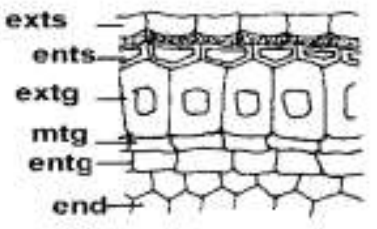

23

Plate 2. Spermoderm anatomy (continued).

Fig. 19. R.odorata, Fig. 20. R.orientalis, Fig. 21. R.phyteuma,

Fig. 23. R.scoparia, Fig. 24. R.stenostachya, Fig. 25. R.stricta,

Fig. 26. R.urnigera, Fig. 27. $R$. villosa.

end=Endosperm; entg=Endotegmen; ents=Endotesta; extg=Exotegmen; exts=Exotesta; $\mathrm{mtg}=$ Mesotegmen; $\mathrm{mts}=$ Mesotesta. 


\section{Key (1) for all the studied taxa of the Resedaceae}

1A. Seed shape reniform

1B Sinus narrow in the form of opened or slightly opened slit

1C. Seed surface tuberculate

1D. Base of tubercle, rectangular or square.

1E. Base striate

Reseda alphonsi

2E. Base rugose- striate

$R$. macrostachya

2D. Base of tubercle wavy margined

R. alba

3D. Base of tubercle not so

1F. Outer periclinal wall of exotesta smooth

R. muricata

$2 \mathrm{~F}$. Outer periclinal wall of exotesta dentate

1G. Outer periclinal wall of exotesta very thick, with more or less ovoid cell lumen ........................................... R. stenostachya

2G. Outer periclinal wall of exotesta thick, with papillose cell lumen

1H. Top of tubercle rugose

R. phyteuma

$2 \mathrm{H}$. Top of tubercle undulate

R. villosa

2C. Seed surface colliculate

1 I. Margin of elevation rugose, base wavy, with rugose top

R. decursiva

2 I. Margin of elevation smooth, base not wavy, with smooth top

$1 \mathrm{~J}$. Radicular lobe longer than the cotyledonary lobe

Ochradenus baccatus

$2 \mathrm{~J}$. Radicular lobe almost as long as the cotyledonary lobe

Randonia africana

3C. Seed surface pusticulate

$1 \mathrm{~K}$. Testa colour yellowish brown ..................................... Reseda complicata

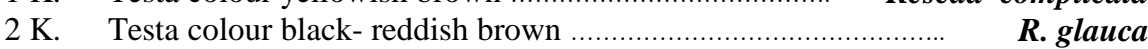

4C. Seed surface areolate to scalariform with irregular straite areole ...... R. pruinosa

2B Sinus very wide

1L Seed surface favulariate

1M. Ridges and furrows surface striate in different directions as network

2M. Ridges and furrows surface lineate in one direction and

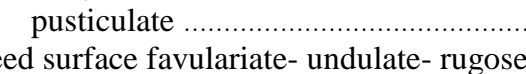

R. media

R. odorata

2 L. Seed surface favulariat
3 L. Seed surface rugose

1N. Ridges and furrows surface ruminate- finely areolate with undulate striations

R. orientalis

$2 \mathrm{~N}$. Ridges and furrows surface finely lineate

R. arabica

R. diffusa

R. luteola

2A Seed shape spherical

3A Seed shape ovoid- pyriform or ovoid

10 Seed surface tuberculate

$2 \mathrm{O}$ Not so

Caylusea hexagyna

1P. Seed arillate

1Q. Seed surface finely areolate- scalariform

R. lutea

2Q. Seed surface finely areolate- globulate

R. crystalina

2P. Seed Exarillate

1R. Seed surface reticulate- granulate [reticulate at seed base, granulate at all surface]

1S. Testa colour greenish black, $0.9 \times 0.7 \mathrm{~mm}$ in dimension ...

R. lanceolata

2S. Testa colour dark olive green $1.1 \times 0.8 \mathrm{~mm}$ in dimensions ...

R. urnigera 
2R. Seed surface areolate with wavy anticlinal walls of exotestal cells

R. scoparia

3R. Seed surface areolate- scalariform

1T. Inner periclinal wall smooth

Oligomeris linifolia

2T. Inner periclinal wall dentate

R. stricta

\section{Key (2) for the Egyptian taxa of Resedaceae}

1A Seed shape reniform

1B Sinus narrow in the form of opened or slightly opened slit

1C. Seed surface areolate to scalariform with irregular striate areoles

Reseda pruinosa

2C. Seed surface colliculate

1D. Margin of elevation rugose, base wavy, with rugose tops

R. decursiva

2D. Margin of elevation smooth, bases not wavy, with smooth tops

1E. Radicular lobe longer than the cotyledonary

lobe

2E. Radicular lobe as long as the cotyledonary

lobe

Ochradenus baccatus

3C. Seed surface tuberculate

Randonia africana

1F. Base of tubercle wavy

2F. Base of tubercle not wavy

$1 \mathrm{G}$. Outer periclinal wall of exotesta very thick, with rectangular cell lumen

R. stenostachya

$2 \mathrm{G}$. Outer periclinal wall of exotesta thick with papillose cell lumen

1H. Outer periclinal wall of exotesta smooth ................ $\quad \boldsymbol{R}$. muricata

2H. Outer periclinal wall of exotesta dentate .................... R. phyteuma

2B Sinus very wide

1I. Spermoderm favulariate to undulate- rugose

R. orientalis

2I. Spermoderm rugose- ruminate

R. arabica

2A Seed shape spherical

R. luteola

3A Seed shape ovoid- pyriform or ovoid

1J Seed surface tuberculate

2J Not so

$1 \mathrm{~K}$. Seed arillate

Caylusea hexagyna

$2 \mathrm{~K}$ Seed exarillate

1L. Seed suface reticulate- granulate

2L. Seed surface areolate- scalariform

R. lutea

R. urnigera

Oligomeris linifolia

\section{Concluding Remarks}

1- As far as the data in the present work are concerned, Reseda alba and R. decursiva are to be treated as distinct species, thus refuting Täckholm's view of considering them as conspecific. This agrees with El- Sayed (1992) who also considered them as distinct species.

2- The present work shows clearly that certain characters are correlated:

a- Where the spermoderm ornamentation is tuberculate, the sinus becomes narrow and opened, the exotesta is formed of more or less pappillose cells and the outer periclinal wall of exotesta is thick and convex, only Caylusea hexagyna is an exception. 
A. E.S. Al-Nowaihi; E.A.K. Karakish; I. F. Ishak \& U.I.A. El-Magly,

b- Where the spermoderm ornamentation is favulariate- ruminate, the sinus becomes very wide, the exotesta rectangular and the outer periclinal wall of exotesta is very thick and dentate.

c- Where the spermoderm ornamentation is areolate to reticulate, the sinus becomes in the form of a shallow groove, the exotesta rectangular and the outer periclinal wall of the exotesta is thin and transparent, only Oligomeris linifolia is an exception.

\section{References}

Abdallah, M.S. \& De Wit, H.C.D. 1978. The Resedaceae. A taxonomical revision of the family. Belmontia, New. Ser. 8: 1- 416.

Argue, C.L 1986. Taxonomic implication of pollen and seed morphology in Mimulus hymenophyllus and M. iungermannioides and comparisons with other putative members of the $M$. moccatus alliance (Scrophulariaceae) Can, J. Bot. Vol. 64. 1331- 1337.

Bacon, J.D.; Bragg, L.H. \& Hannan, G.L. 1986. Systematics of Nama (Hydrophyllaceae): Comparison of seed morphology of Sect. Arachnoidea and Cincrascentia with five species of Eriodictyon and Turricula. Parryi. Sida, 11: 271- 281.

Chaung, T.I. \& Heckard, L.R. 1983. Systematic significance of seed surface features in Orthocarpus (Scrophulariaceae tribe Castillejinae) Amer. J. Bot. 70 (6): 877- 890.

Corner, E.J.H. 1954. The durian theory extended II. Phytomorphology 4: 152- 165. 1976. The seeds of dicotyledons. Vol. 1\& 2, Cambridge University Press.

Cronquist, A. 1968. The Evolution and Classification of Flowering Plants. Thomas Nelson and Sons. Ltd., London.

De leonardis, W.; Fichera, G.; Longhitano, N. \& Zizza, A. 1997. Pollen and seed morphology of three species of Reseda L. in Sicily and relationship with their systematic position. Pl. Biosystems. 131 (1): 43- 49.

El- Sayed, M.T. 1992. A taxonomical study on the Resedaceae, M.Sc.Thesis. Zagazig University.

Grant. A.L. 1924. A monograph of the genus Mimulus. Ann. Mo. Bot. Grad. 11: 99- 339.

Guignard, G. 1986. Les grains du genre Digitalis. (Scrophulariaceae) Can. J. Bot. 64: 13891396.

Johansen. D.A. 1940. Plant Microtechnique, New York, Book Company p. 523.

Murley, M.R. 1951. Seeds of Cruciferae, Amr, Midl. Nat. 46: 1- 81.

Netolitzky, F. 1926. Anatomie der Angiospermen Samen $\mathbf{1 0}$ in Handbuch der Pflanzenanatomie Abt II (2): 144- 145. Linbauer. Berlin.

Pemberton, R.W. \& Irving, D.W. 1990. Elaiosomes on weed seeds and the potential for myrmecochory in naturalized plants. Weed-Science. 38, 6: 615- 619.

Stebbins, G.L. 1974. Flowering Plants. Evolution Above the Species Level: 283- 311 \& 399. E. Ward Arnold, Ltd. London.

Täckholm, V. 1974. Students' Flora of Egypt. (ed 2): 206- 211, Cairo University.

Tobe, H. \& Raven, P.H. 1991. The embryology and relationships of Gyrostemonaceae. Aust. Syst. Bot. 4: 407- 420.

Wyatt, R. 1984. Intraspecific variation in seed morphology of Arenaria uniflora (Caryophyllaceae). Syst. Bot. 9: 423- 431. 